\title{
PROFILE OF STUDENTS OCEAN LITERACY AT SENIOR HIGH SCHOOL IN MATARAM
}

\author{
Lalu Hasan Nasirudin Zohri ${ }^{1 *}$, Irmayani ${ }^{1}$, Yufika Dewi Muksin ${ }^{1,3}$, Abdul Syukur ${ }^{2}$, Jamaludin $^{2}$ \\ ${ }^{1}$ Magister of Science Education, Postgraduate Study University of Mataram, Mataram, Indonesia \\ ${ }^{2}$ Biology Education Study Program FTTE University of Mataram, Mataram, Indonesia \\ ${ }^{3}$ Laboratory of Immunobiology, University of Mataram, Mataram, Indonesia \\ *Email: laluhasanbio16@gmail.com
}

\author{
Acceped: July 29 2021. Approved: Sept 01 2021. Published: Sept 042021
}

\begin{abstract}
Ocean literacy is knowledge about the biophysical and ecological aspects of the ocean that have relevance to the topic of biology learning. This study aims to classify the profiles on ecosystem topics of the ocean literacy of the high school students of SMA 1 Mataram. This study uses an observational approach with a purposive sampling technique, while the data analysis used is descriptive statistical analysis. Furthermore, the samples of this study are 186 of 848 students. The classification of students' literacy on ocean ecological aspects in SMA 1 Mataram are: the percentage of correct answers on indicator 1 is $41.55 \%$, indicator 2 is $68.55 \%$, and indicator 3 is $41.40 \%$. This study concludes that high school students at the study site have not had sufficient knowledge about ocean ecology. However, some materials, such as ocean ecosystems, can be a source of learning to improve students' literacy about ocean ecologies, such as tropical structures in a coral reef, seagrass, and mangrove ecosystems. Therefore, it is necessary to innovate learning resources from ocean environments, especially schools close to the sea, such as a high school in the study site and other high schools in other places.
\end{abstract}

Keywords: ocean literacy, profiles, category, ecosystem matter

\section{INTRODUCTION}

Ocean literacy is one's ability and attitude towards the ocean that positively impacts the sea or the same reciprocity for humans [1,2,3]. Marine content that is considered essential to be implemented in learning includes seven aspects: the earth has oceans with many properties and a variety of characteristics, the oceans and the life in the oceans form the nature or condition of the earth, the oceans are the main factor that affects the climate, the oceans make the earth habitable, the oceans support biodiversity and ecosystems, the oceans and the humans are inseparable and interconnected, and the oceans are largely unexplored [2]. Through these seven aspects, students are expected to be able to fulfill three indicators. First, understand the essential principles and basic concepts of the ocean's functions. Secondly, they can communicate about oceans in a meaningful way and make responsible decisions about the use of ocean resources [2].

Aspects and indicators of ocean literacy are very relevant to be applied at the high school level on ecosystem material in terms of the curriculum's scope in Indonesia. However, there are no specific subjects on marine affairs. The Ministry of Education and Culture and the Coordinating Ministry for Marine Affairs have collaborated to develop and implement a national maritime curriculum since President Jokowi's administration took office. However, there is still no clarity until now [4,2]. However, there is a lot of content about ocean life in the high school curriculum on material pieces and basic competencies that support ocean literacy spread over intersecting subjects, especially Biology [5]. In biology subjects listed in the curriculum, comprehensive ecosystem material can represent marine content at the high school level [6]. Thus, the integration of ocean literacy contents can be conducted at the high school level through one alternative, i.e., ecosystem materials [7].

The ecosystem material studied by students in the Indonesian curriculum is found in the Grade $\mathrm{X}$ of senior high school [6]. The material can represent ocean content because the sub-discussions are related to marine content. The sub-discussions are expected to include: ocean zones, ocean ecosystems, energy flows, biogeochemical cycles, and ecological pyramids. Thus, these materials can be used as a means of obtaining students' ocean literacy profiles.

The literacy status of Indonesian students is currently still below the average literacy rate of students in the world. It can be seen by representing mathematical literacy scores, reading literacy, and scientific literacy conducted by the OECD (Organization of Economic Corporation and Development). Researches by OECD conducted three times $(2012,2015$, and 2018) in the last ten years showed unsatisfactory results for Indonesia $[8 ; 9 ; 10]$. Mathematical literacy shows scores of 375, 386, and 379 , reading literacy shows 396,397 , and 371 , and scientific literacy shows 382, 403, and $396[8,9,10]$. This result is a significant blow to Indonesian education because there is no significant improvement; even a decline in the literacy skills of Indonesian students occurs. Even worse, in 2000, for the first time, PISA conducted research on the average growth of Indonesian literacy scores. The scores were only 1 for reading, 2 for mathematics, and 3 for science [10]. The low literacy scores of Indonesian students in various literacy branches raise questions; What is the profile of Indonesian students' ocean literacy, populations of maritime countries? 
Ocean literacy profiles are very important to know as input for education units, local governments, and central governments regarding the context of the ocean-based curriculum [7], especially for those in the development period. The importance of ocean literacy in the learning process should present a lot of research on ocean literacy in education. Data and studies of ocean literacy in Indonesia are still very few [9]. Data and studies of ocean literacy in Indonesia are still very few [9]. Information about ocean literacy is vital to support the realization of the maritime-based national development reorientation. It has been intensively promoted by the Government of Indonesia recently [5].

Based on the interview results with a Biology teacher at SMA 01 Mataram, no research has been related to ocean literacy. In learning, the teacher has integrated the ocean aspect in learning through students' worksheets. In the ecosystem material closely associated with the ocean and has been taught, the teacher said that students could integrate the ecosystem materials with the ocean. Based on the urgency of ocean literacy, the lack of data, especially the absence of ocean literacy research at SMA 01 Mataram, it is considered necessary to research "Profile of Students' Ocean Literacy through Ecosystem Materials for Grade X of Senior High Schools". This research is expected to be an initiator for other researchers and a source of information for policymakers and practitioners in learning ocean literacy.

\section{RESEARCH METHOD}

\section{Type, Site, and Time of Study}

This study is a descriptive approach. It intends to describe the profile of students' ocean literacy by scientific method. It was conducted at SMAN 1 Mataram, which was conducted in MarchJune 2021.

\section{Population and Sample}

The population of this study was all students of MIPA Classes at SMAN 1 Mataram totaling 848 students. The determination of the sample used the purposive sampling technique consisted of 186 students of 8 classes: Grade X of Mathematics and Science (MIPA) 1 to Grade X MIPA 8.

\section{Instruments and Data Analysis}

Data collection was conducted using an ocean literacy test instrument based on ecosystem materials. The data analysis technique used a categorical percentage approach by calculating feasibility results [11] using the following formula.

$$
\text { Percentage }=\frac{\text { Observed Score }}{\text { Expected Score }} \times 100 \%
$$

The percentage results were then used to answer the feasibility of the aspects studied with the categories in Table 1.

Table 1 . Feasibility categories

\begin{tabular}{ll}
\hline Percentage $(\%)$ & Category \\
\hline$<21 \%$ & Very poor \\
$21 \%-40 \%$ & Poor \\
$41 \%-60 \%$ & Sufficient \\
$61 \%-80 \%$ & feasible \\
$81 \%-100 \%$ & Very feasible \\
\hline
\end{tabular}

\section{RESULTS AND DISCUSSIONS}

\section{Overview of Students' Ocean Literacy}

This study succeeded in identifying the level of 186 samples of students' ocean literacy with an average score of 50.5. The majority of the students in this study were in the sufficient category with $43 \%$, and there was only $2.15 \%$ in the very feasible category (Figure 1).

\section{Students' Ocean Literacy in Each Indicator}

This study used ocean literacy indicators promoted by Schrodinger [2], which consists of 3 indicators. This research instrument, indicator one, is represented by questions number 1-4, indicator two by questions number 5-8, and indicator three by questions numbers 9-12. The study results showed that indicators 1 and 3 tended to be answered incorrectly by students, while indicator 2 led the opposite, where more students managed to answer it correctly (Table 2).

\section{Overview of Students' Ocean Literacy}

The ocean literacy profile of SMA 01 Mataram students has an average score of 50.5 with a distribution of $8.6 \%$ in the inferior category, $15.59 \%$ in the poor category, $43 \%$ in the sufficient category, $30.11 \%$ in the feasible category, and only $2.15 \%$ of students in the very feasible category (Figure 1). When compared to other maritime countries, the marine literacy score obtained is generally still below the countries. In Latin America, students' ocean literacy in Nova-scotia, Canada, $50 \%$ of the total sample of 723 students from 11 schools were in the very feasible category [12]. The score in this study was far lower than in other Asian countries, where the Taiwanese students' ocean literacy score was taken from 496 samples from 7 schools got an average score of $63 \%$ [13]. Meanwhile, compared to the European countries, Indonesia has an ocean literacy score higher than Greece and below the UK and Mediterranean countries. The average ocean literacy score in the United Kingdom with a sample of 132 is 61 , and in Portugal, with a sample of 328 , it is 52 in the range 1100 [14]. The ocean literacy profile of the Mediterranean countries, i.e., Italy, Croatia, and Greece, with a total sample of 1004 students, got an average score of 57.4, 54.0, and 48.6, respectively [2]. 


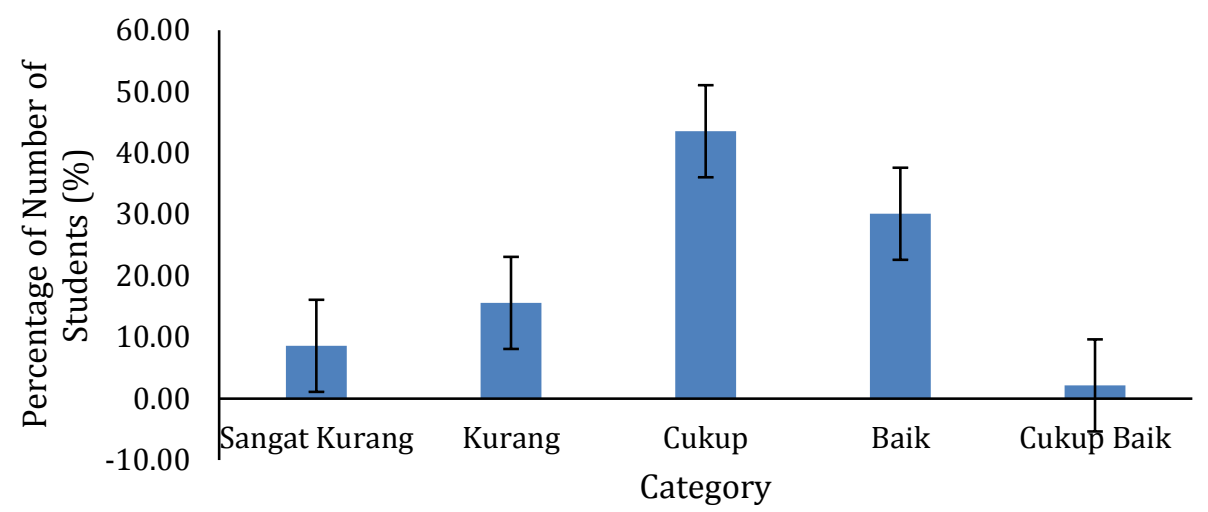

Figure 1. Categorical percentage of students' ocean literacy

Table 2. Percentage of numbers of correct and incorrect answers

\begin{tabular}{lccc}
\hline \multicolumn{1}{c}{ Indicators } & Instrument No. & $\begin{array}{c}\text { Percentage of Students } \\
\text { Answering Correct }\end{array}$ & $\begin{array}{c}\text { Percentage of Students } \\
\text { Answering Wrong }\end{array}$ \\
\hline Indicator 1 & 1 & $67,20 \%$ & $32.800 \%$ \\
& 2 & $32,30 \%$ & $67.700 \%$ \\
& 3 & $55,40 \%$ & $44.600 \%$ \\
& 4 & $11,30 \%$ & $88.700 \%$ \\
\hline Average & 5 & $41,55 \%$ & $58,45 \%$ \\
\hline Indicator 2 & 6 & $46,80 \%$ & $53.200 \%$ \\
& 7 & $91,90 \%$ & $8.100 \%$ \\
& 8 & $65,10 \%$ & $34.900 \%$ \\
Average & 9 & $70,40 \%$ & $29.600 \%$ \\
\hline Indicator 3 & 10 & $68,55 \%$ & $31,45 \%$ \\
& 11 & $19,90 \%$ & $80,100 \%$ \\
& 12 & $17,70 \%$ & $82,300 \%$ \\
& & $48,40 \%$ & $51,600 \%$ \\
\hline Average & & $79,60 \%$ & $20,400 \%$ \\
\hline Overall Average & & $41,40 \%$ & $58,60 \%$ \\
\hline Information: & & $50,50 \%$ & $49,50 \%$ \\
\hline
\end{tabular}

Indicator 1: Understand the essential principles and fundamental concepts of ocean function. Indicator 2: Able to communicate about the ocean in a meaningful way Indicator 3: Able to make responsible decisions on the ocean and its resources

Research on accountable ocean literacy in Indonesia is still challenging to find. However, when compared with the scientific literacy profile in the Mataram area, the score of SMA 01 Mataram students is still higher, where the average scientific literacy score of the majority of the Mataram area is in the medium category with $48.2 \%$. The very high category has a percentage of $0.0 \%$, high category with $3.6 \%$, low category with $13.4 \%$, and very low category with $34.8 \%$ [15].

Compared to the countries mentioned above, the low level of students' ocean literacy in this study can be caused by several things, such as the curriculum that is still less specific in supporting marine content in education units [4]. Compared to UK and Canada, which have applied maritime-based education, Indonesia is even seen to be very late in planning the application of a maritime-based curriculum [5]. Thus, it is very reasonable that
Canadian and British students' scores are higher than Indonesian. The lack of curriculum is that students lack knowledge of basic content and a high level of an integrated understanding of the relationship between humans and the ocean, which is manifested in the lower scores of the students in this study [2].

\section{Students' Ocean Literacy on Each Indicator}

Based on each indicator (Table 2), it can be seen that indicator 1 shows that the number of incorrect answers is relatively higher than the number of correct ones. It shows that student's ability to understand essential principles and fundamental concepts of ocean function is still weak. For example, a fairly high number of incorrect answers is found in question number 4 (Table 2). This condition can be caused by the inability of students to understand the concept of the ocean in the question, where there were marine zones represented by pictures and then the 
students are asked to identify the correct statement regarding the marine zone. In fact, in Grade X teaching materials, many pictures are displayed to describe the location of the ecosystems in the ocean. Indicator 2 shows that the number of correct answers is real pictures represented marine zones. It shows that most students' communication or delivery skills about the ocean aspect are quite good. For example, a relatively high number of correct answers is found in question number 6 (Table 2), where a graph of the age percentage of lobster caught in South Lombok was shown, and students were asked to determine the number of 15-week-old lobsters caught. It shows that students have good skills in reading charts or communicating data about the ocean in statements. Indicator 3 shows that the number of incorrect answers is relatively higher than the number of correct answers. It identifies that students are still weak in making decisions about the ocean based on the phenomena that have been presented. For example, a high number of incorrect answers were found in questions 9 and 10, which showed an ocean problem, and students were asked to choose the most appropriate decision (Table 2).

\section{CONCLUSION}

The studied high school students have not had sufficient knowledge about ocean ecological content. It can be seen from the profile of students' ocean literacy that is on the average of 50.5, with the majority being in the sufficient category with $43 \%$, and there was only $2.15 \%$ of them were in the very good category. Then, based on each indicator, indicators 1 and 3 show that students who answered incorrectly are relatively more than those who answered correctly. In contrast, indicator 2 shows the opposite, where relatively more students answered correctly.

\section{Recommendation}

It is recommended for educators to innovate learning resources from ocean environments, especially schools located close to the sea, such as the high school in the study site and other high schools in other places.

\section{REFERENCES}

[1] Cava, F., Schrodinger, S., Strang, C., \& Tuddenham, P. (2005). Science content and standards for ocean literacy: A report on ocean literacy. National Oceanic and Atmospheric Administration.

[2] Schoedinger, S., Cava, F., \& Jewell, B. (2006). The Need for Ocean Literacyin the Classroom. The Science Teacher.

[3] Strang, C., DeCharon, A., \& Schoedinger, S. (2007). Can you be science literate without being ocean literate? Current. The Journal of Marine Education. 23(1), 7-9.
[4] KEMENTERIAN KOORDINATOR BIDANG KEMARITIMAN DAN INVESTASI. 2021. Beri Acuan Implementasi Kurikulum Kemaritiman. Diakses melalui https://maritim.go.id/beriacuan-implementasi-kurikulumkemaritimankemenko-maritim-undang-sekolahdasar-dan-menengah-se-indonesia/ pada Ahad 20 Juni 2021.

[5] Hindrasti, N. E. K dan Irawan, B. (2018). Pengembangan Instrumen Literasi Kelautan Untuk Siswa SMA. Jurnal Kiprah. 4 (2): 1-7.

[6] Peraturan Menteri Pendidikan Dan Kebudayaan Republik Indonesia Nomor 37 Tahun 2018. Tentang Perubahan Atas Peraturan Menteri Pendidikan Dan Kebudayaan Nomor 24 Tahun 2016 Tentang Kompetensi Inti Dan Kompetensi Dasar Pelajaran Pada Kurikulum 2013 Pada Pendidikan Dasar Dan Pendidikan Menengah.

[7] Runianto, E. (2019). Profil Literasi Kelautan Siswa Sman 5 Tanjungpinang. Profil Literasi Kelautan Siswa Sman 5 Tanjungpinan. Respostori Universitas Maritim Raja Ali Haji.

[8] OECD. (2014). PISA 2012 Results in Fokus What 15-Years-Olds Know and What They Can Do whit What They Know. Paris.: PISAOECD Publishing.

[9] OECD. (2016). PISA 2015 Assesment and Analitycal Framework: Science, Reading, Mathematic and Financial Literacy. Paris: PISA OECD Publishing.

[10] OECD. (2018). PISA Resultes in Fokus. Rusia: OECD Publishing.

[11] Arikunto, S., 2009. Prosedur Penelitian Suatu Pendekatan Praktik. Edisi Revisi 6. Jakarta : Rineka Cipta.

[12] Guest, H., Lotze, H. K., \& Wallace, D. (2015). Youth and the sea: Ocean literacy in Nova Scotia, Canada. Marine Policy, 58, 98-107.

[13]Lin, Y. L., Wu, L. Y., Tsai, L. T., \& Chang, C. C. (2020). The Beginning of Marine Sustainability: Preliminary Results of Measuring Students' Marine Knowledge and Ocean Literacy. Sustainability, 12(17), 7115.

[14]Leitão, R., Maguire, M., Turner, S., Guimarães, L., \& Arenas, F. (2018, March). Ocean literacy and information sources: comparison between pupils in Portugal and the UK. In 12th annual International Technology, Education and Development Conference (pp. 5058-5067).

[15] Merta, I. W., Artayasa, I. P., Kusmiyati, K., Lestari, N., \& Setiadi, D. (2020). Profil Literasi Sains dan Model Pembelajaran dapat Meningkatkan Kemampuan Literasi Sains. Jurnal Pijar MIPA, 15(3), 223-228. 